\title{
ACTUAL PROBLEMS OF COOPERATION WITH ORGANIZATION OF FOREIGN STATES IN THE SPHERE OF FORENSIC EXPERT ACTIVITY
}

\author{
Simakova-Efremian E. B., Derecha L. M., Myasoedov V. V.
}

The article shows the role of international cooperation in the field of forensic expert activity. On development of forensic expert institutions of the Ministry of Justice of Ukraine and the expansion of the possibilities for forensic examinations have a positive effect their activity in the implementation of international contacts: the organization of joint international scientific and practical conferences, seminars, internship of specialists with the purpose of sharing work experience, training of forensic experts, familiarization with the organization of activities and advanced methods of conducting forensic examinations and expert studies, allows a specialist there constantly to be aware of the latest achievements of science and to use the experience of their colleagues from other countries. Currently, work is underway to conduct joint scientific developments, training of highly qualified scientific personnel, but this is not specified in Art. 24 of the Law of Ukraine "On forensic science", and therefore we propose this article be amended as follows: "State specialized institutions that perform forensic examinations are entitled establish international scientific ties with the institutions of forensic science, criminalistics and other states for the purpose of joint research and development, exchange of scientific and methodological information and printed publications, use of common international information funds, data banks, training, retraining and advanced training of forensic experts, international conferences, symposia, seminars, joint publications in forensic science and criminalistics, training of highly qualified scientific personnel". In connection with the further development of international cooperation, it is desirable in the structure of forensic institutions to provide for such a unit as the International Relations Department. In 2018, KhRIFE obtained the Accreditation Certificate for compliance with the requirements of the international standard ISO/IEC 17025. The collection of scientific proceedings "Theory and Practice of Forensic Science and Criminalistics" is included in the international scientometric database Index Copernicus. The development of international cooperation in the field of forensic science will contribute to enhancing the scientific and methodological potential of forensic expert institutions, developing new directions and types of forensic expert activity, and increasing the effectiveness of the fight against crime.

Keywords: forensic expert activity, international cooperation, research institutions of forensic examinations, experience exchange, internships, cooperation, international treaty.

DOI: https://doi.org/10.32353/khrife.2018.20

УДК 343.1

М. Г. Щербаковський, професор кафедри кримінально-правових дисциплін Харківського національного університету внутрішніх справ, доктор юридичних наук, доцент

E-mail: shcherbakovskyi@gmail.com

\section{СУТНІСТЬ, СТРУКТУРА ТА ЦЛІ ВИКОРИСТАННЯ СПЕЦІАЛЬНИХ ЗНАНЬ У СУДОЧИНСТВІ}

Розглянуто характеристики спеціальних знань. Показано, що знання $\epsilon$ відомостями з різних галузей діяльності, крім права, спеціальними іменуються тільки в судочинстві, набуваються в процесі навчання й практично-

(C) Щербаковський М. Г., 2018 
го досвіду, використовуються на основі умінь $і$ навичок у процесуальній i непрочессуальній формах із метою отримання доказової та орієнтуючої інформації.

Ключові слова: спечіальні знання, судочинство, правові знання, форми й цілі використання спеціальних знань.

Спеціальні знання - найбільш дискусійне поняття в теорії будь-якого виду судочинства. Зміст, форми використання та суб'єкти застосування спеціальних знань у розслідуванні злочинів, судовому розгляді кримінальних, цивільних, адміністративних, господарських справ постійно привертають увагу процесуалістів, криміналістів, судових експертів. Питання щодо природи спеціальних знань сьогодні, як і протягом багатьох років, інтенсивно обговорюють у наукових колах. Правники досліджують їх окремо або під час розгляду особливостей доказування. Учені намагаються розкрити поняття спеціальних знань, зазначити їх обсяг, особливі риси й ознаки, проте дотепер жодна з позицій дослідників не $є$ загальновизнаною, що свідчить про необхідність подальшого розроблення цієї проблематики. Вагомий внесок у дослідження проблем застосування спеціальних знань у судочинстві зробили українські науковці С. С. Бичкова, О. О. Бондаренко, Т. В. Варфоломєєва, В. Д. Глушкова, В. Г. Гончаренко, І. В. Гора, Н. І. Клименко, В. В. Коваленко, О. А. Комаха, А. Т. Комзюк, М. В. Костицький, О. А. Кравченко, В. К. Лисиченко, Г. М. Надгорний, І. В. Пиріг, В. М. Ревака, Р. М. Романенко, Б. В. Романюк, К. А. Садчикова, М. Я. Сегай, В. В. Семенов, 3. М. Соколовський, В. В. Ціркаль, Ж. В. Васильєва-Шаламова, В. Ю. Шепітько та ін. Серед зарубіжних учених феномен спеціальних знань досліджували Т. В. Авер'янова, В. Д. Арсеньєв, О. П. Гришина, А. Г. Давтян, О. О. Ексархопуло, О. О. Зайцева, О. М. Зінін, П. П. Іщенко, Л. М. Ісаєва, Ю. Г. Корухов, Л. В. Лазарєва, Т. А. Лілуашвілі, В. М. Махов, Ю. К. Орлов, М. О. Радіонова, О. Р. Россинська, О. В. Селіна, І. М. Сорокотягін, В. В. Степанов, Т. Д. Телегіна, І. І. Трапезнікова, М. К. Треушніков, Л. Г. Шапіро, С. А. Шейфер, С. П. Щерба та ін. Водночас серед учених і практиків досі немає єдиної думки щодо ключових проблем цієї процесуальної категорії.

Метою статті $\epsilon$ аналіз точок зору науковців і формулювання авторської позиції щодо сутності спеціальних знань, їх змісту, форм і цілей використання.

Процесуальне законодавство України не розкриває зміст поняття «спеціальні знання», пов'язуючи їх використання із призначенням експертизи або залученням спеціаліста. Почнемо розгляд поняття «спеціальних знань» 3 філософського його трактування. У філософії термін «знання» тлумачать як «особливу форму духовного засвоєння результатів пізнання (процесу відтворення дійсності), що характеризується усвідомленням їх істинності» ${ }^{1}$, розуміють як сукупність відомостей із якої-небудь галузі, набутих у процесі навчання, дослідження тощо; пізнання дійсності в окремих іiі проявах

1 Філософський енциклопедичний словник / гол. ред. В. І. Шинкарук. Київ : Абрис, 2002. С. 228. 
і в цілому ${ }^{1}$. Знання є системою ідеально відтворених у мовній або знаковій формі закономірних зв'язків об'єктивного світу, а різні форми знання зв'язані зі способами діяльності людини. Прийнято виділяти два види знань практичні (повсякденні) та наукові. Практичні знання є узагальненням досвіду виробничої, політичної, лікарської, педагогічної та інших форм діяльності, містять певні рекомендації і приписи. Під практичними знаннями розуміють знання, накопичені людьми в побуті та повсякденній виробничій діяльності, виражені в так званих рецептурних правилах ${ }^{2}$. Основою наукового (теоретичного) знання слугує дослідницька діяльність - процес отримання нового знання на основі осмислення результатів попереднього розвитку ${ }^{3}$. Наукові знання являють собою розгалужену систему знань. Вони стають доступними людині тільки в результаті пізнавальної діяльності на рівні теоретичного мислення, що грунтується на відповідній (спеціальній) освітній підготовці. Очевидно, що практичні й наукові знання взаємозалежні та взаємозумовлені.

В. Д. Арсеньев і В. Г. Заблоцький, 3. М. Соколовський розглядають спеціальні знання як сукупність, систему відомостей ${ }^{4}$, Т. Д. Телєгіна уточнює, що це - «відомості наукового та ненаукового характеру» ${ }^{5}$ О. П. Гришина трактує спеціальні знання як комплекс різноманітної інформації́. Спеціальні знання, на думку В. Ю. Шепітько, є системою наукових даних (відомостей) або навичок об'єктивного характеруㄱ. Ми приєднуємося до думки цих науковців, оскільки визначення спеціальних знань як сукупності систематизованих відомостей або інформації з різних сфер людської діяльності видається більш точним і відповідає філософському та гносеологічному трактуванню цього поняття.

«Спеціальний» визначається в словнику як «призначений виключно для кого-, чого-небудь, який має особливе призначення, належить до окремої галузі чого-небудь, властивий тій чи іншій спеціальності» ${ }^{8}$. Поняття «спе-

1 Новий тлумачний словник української мови : у 4 т. / уклад. В. Яременко, О. Сліпушко. Київ : Аконіт, 1999. Т. 2. С. 162.

2 Надгорный Г. М. Гносеологические аспекты понятия «специальные знания». Криминалистика и судебная экспертиза. Киев : Вищ. шк., 1980. Вып. 21. С. 39. C. 259.

3 Философия : учебник / под ред. О. Митрошенкова. Москва : Гардарики, 2002.

4 Арсеньев В. Д., Заблочкий В. Г. Использование специальных знаний при установлении фактических обстоятельств уголовного дела. Красноярск: Красноярский гос. ун-т, 1986. С. 4; Соколовский 3. М. Понятие специальных знаний (к вопросу о назначении экспертизы). Криминалистика и судебная экспертиза. Киев : РИО МВД УССР. 1969. Вып. 6. С. 202.

5 Телегина Т. Д. Использование специальных знаний в современной практике расследования преступлений : монография. Москва : Юрлитинформ. 2011. С. 28.

6 Гришина $E$. П. Сведущие лица в российском уголовном судопроизводстве: теоретические проблемы доказывания и правоприменительная практика : монография. Москва : Юрлитинформ. 2012. С. 14.

7 Шепітько В. Ю. Проблеми використання спеціальних знань крізь призму сучасного кримінального судочинства в Україні. Судова експертиза. 2014. № 1. С. 11.

8 Словник української мови : у 11 т. Київ : Наук. думка, 1978. Т. 9. С. 501-502. 
ціальні знання» слід розглядати в широкому сенсі як знання в будь-якій сфері людської діяльності. В такому трактуванні юридичні (правові) знання, безумовно, є спеціальними, набуваються шляхом навчання та ними зобов'язані володіти професійні учасники судочинства, які здійснюють доказування й судовий розгляд. Однак в епістемології, теорії пізнання словосполучень «спеціальні знання», «спеціальні наукові знання» не існує. Як правильно зазначає А. Ф. Волобуєв, у кримінально-процесуальному законодавстві термін «спеціальні знання» використовується на противагу обов'язковим юридичним знанням, якими повинні володіти юристи-професіонали ${ }^{1}$. Тому поняття «спеціальні знання» у вузькому сенсі вживається тільки в галузі судочинства й належать до тезаурусу правової сфери.

Отже, зміст спеціальних знань становить система відомостей (інформації) з різних галузей наукової або практичної діяльності, крім права, яка використовується в судочинстві. Обговоримо ознаки, якими науковці наділяють спеціальні знання.

Одним із перших юристів, хто дав визначення спеціальним знанням, був О. О. Ейсман, який указав на те, що вони не є загальновідомими та загальнодоступними ${ }^{2}$. Ці ознаки вказують і сучасні автори ${ }^{3}$. Відомий учений О. Р. Россинська підкреслює, що співвідношення спеціальних і загальновідомих знань за своєю природою мінливе, залежить від ступеня розвитку соціуму та рівня інтегрованості наукових знань у повсякденне життя людини ${ }^{4}$. На думку Т. В. Сахнової, визначення спеціальних знань має оціночний характер і тому за своєю природою залежить від рівня розвитку суспільних відносин та адаптації наукових знань у життєвому досвіді людини ${ }^{5}$. Другий критерій «незагальнодоступність» знань також втрачає своє значення, оскільки в сучасних умовах глобальної інформатизації суспільства, наявності всесвітньої мережі Інтернет можна отримати будь-яку інформацію з різних сфер науки, техніки, суспільства тощо. Тому критерії «незагальновідомість» або «незагальнодоступність» не можуть бути ознакою спеціальних знань.

Найчастіше до спеціальних відносять сукупність знань у певній галузі науки, техніки, мистецтва, ремесла ${ }^{6}$. Вичерпний перелік чотирьох галузей спеціальних знань фактично відтворює положення статей 112 и 325 Статуту кримінального судочинства 1864 р.7 Таке трактування спеціальних знань

1 Волобуєв А. Ф. Проблеми методики розслідування розкрадань майна в сфері підприємництва : монографія. Харків : Ун-т внут. справ, 2000. С. 236.

2 Эйсман A. A. Заключение эксперта (структура и научное обоснование). Москва : Юрид. лит., 1967. С. 91.

Експертизи у судочинстві України : посібник / за заг. ред. В. Г. Гончаренка, I. В. Гори. Київ : Юрінком Інтер, 2015. С. 11.

4 Россинская E. Р. Специальные познания и современные проблемы их использования в судопроизводстве. Журнал российского права. 2001. № 5. С. 40.

5 Сахнова Т. В. Судебная экспертиза. Москва : Городец, 2000. С. 9.

6 Когутич I. I. Окремі питання сутності та форм використання спеціальних знань у кримінальному провадженні. Вісник Академії адвокатури України. 2015. T. $12 / 2$ (33). C. 114.

7 Устав уголовного судопроизводства 1864 г. URL: http:/constitution.garant.ru/ history/act1600-1918/3137 (дата звернення: 01.08.2018). 
надається у визначеннях багатьма сучасними науковцями ${ }^{1}$. Вітчизняний законодавець обмежив перелік конкретних галузей спеціальних знань науковими й технічними знаннями та вказав на «інші спеціальні знання» (ст. 69 КПК України). На наш погляд, нині не актуальні сформульовані в XIX ст. галузі спеціальних знань, що використовуються в будь-яких видах судочинства. На сучасному етапі, з урахуванням того, що, по-перше, злочини вчиняються чи не в усіх сферах людської діяльності з використанням найрізноманітніших новітніх технологій, по-друге, в процесі встановлення обставин правопорушення можуть бути використовувані знання з будь-якої галузі, від наведеної трактовки спеціальних знань шляхом їх перерахування слід відмовитися, адже дати вичерпний перелік видів таких знань неможливо. Крім того, слід звернути увагу на відсутність логіки в зазначеному переліку. Наприклад, важко викремити знання в мистецтві (знання художника та ін.) від знань в мистецтвознавстві як науки й знань у художніх промислах як виду ремесел.

Відповідно до законодавства експерту заборонено вирішувати питання 3 галузі права (ст. 242 КПК України, ст. 102 ЦПК України, ст. 98 ГПК України, ст. 101 КАС України), а отже, можна дійти висновку, що правові знання законодавець не включає в коло спеціальних. Однак за останні роки теза щодо протилежності правових і спеціальних знань у судочинстві зазнає суттєвої ревізії. Аналіз існуючих думок науковців дозволяє виділити такі основні підходи до співвідношення правових знань із спеціальними в кримінальному провадженні. До спеціальних знань, крім не правових, віднесені: криміналістичні знання ${ }^{2}$; правові, крім професійних знань суб'єктів, які здійснюють кримінальне провадження ${ }^{3}$; правові знання, крім криміналь-

1 Кримінальний процесуальний кодекс України: наук.-практ. коментар / за заг. ред. В. Г. Гончаренко, В. Т. Нора, М. Є. Шумила. Київ : Юстініан. 2012. С. 202, 539; Кримінальний процесуальний кодекс України: наук.-практ. коментар / відп. ред. С. В. Ківалов, С. М. Міщенко, В. Ю. Захарченко. Харків : Одіссей. 2013. С. 592; Юрчишин В. Д. Висновок експерта як джерело доказів у кримінальному процесі України : автореф. дис. ... канд. юрид. наук : 12.00.09. Київ, 2006. С. 8; Навчальнометодичний посібник для самостійної роботи та практичних занять і словник термінів 3 навчальної дисципліни «Криміналістика» / уклад. В. Ю. Шепітько, В. О. Коновалова, В. А. Журавель та ін. Харків : Нац. ун-т «Юридична академія України ім. Ярослава Мудрого». 2013. С. 147 та ін.

2 Надгорный Г. М. Соотношение специальных и юридических знаний. Криминалистика и судебная экспертиза. Киев : Вищ. шк., 1984. Вып. 28. С. 18; Клименко Н. И. Ошибки при использовании специальных знаний в досудебных стадиях уголовного процесса. Проблемы дальнейшего укрепления соичиалистической законности при расследовании преступлений органами внутренних дел : сб. науч. тр. Киев : Киев. гос. ун-т. 1988. С. 127.

Бондаренко О. О. Процесуальний статус обізнаних осіб та їх правовідносини 3 дізнавачем і слідчим у кримінальному судочинстві України : дис. ... канд. юрид. наук : 12.00.09. Харків, 2004. С. 16. Ревака В. М. Форми використання спеціальних пізнань в досудовому провадженні : дис. ... канд. юрид. наук : 12.00.09. Харків, 2006. C. 177. 
ного процесу та кримінального права ${ }^{1}$; правові знання, крім матеріального та процесуального права ${ }^{2}$; усі правові знання ${ }^{3}$. Ми приєднуємося до тих учених, які розглядають спеціальні знання виключно як неправові ${ }^{4}$ І Інша позиція відкриває дорогу до залучення фахівців-правознавців, які в змозі замінити професійних учасників процесу, та проведення правових експертиз, що прямо заборонено законом. Із цього приводу слід указати на явну помилку законодавця, який увів до цивільного, господарського та адміністративного процесів такого нового учасника як «експерт з питань права» (ст. 73 ЦПК України, ст. 70 ГПК України, ст. 68 КАС України) 5 . Крім того, що поява цієї особи вносить плутанину в самі процесуальні закони, які забороняють експертним шляхом вирішувати питання права, висновок такого експерта не має силу джерела доказів, а має консультаційний характер. Тому правильніше називати такого фахівця «консультантом із питань права».

Із появою і розвитком науки про судову експертизу - судової експертології природно встає питання щодо іiі співвідношення зі спеціальними знаннями експерта. Судова екпертологія, на наш погляд, складається із загальної теорії експертиз і методологічних основ різних судово-експертних галузей, які використовуються для розроблення експертних методів і методик дослідження різних об'єктів із метою розв'язання типових завдань. Уявляється, що до спеціальних знань належать методи й методики, котрі становлять арсенал спеціальної частини судової експертології, які експерти застосовують у процесі проведення досліджень і вирішення поставлених питань ${ }^{6}$.

1 Степанюк Р. Л., Лапта С. П. Співвідношення правових і спеціальних знань у кримінальному провадженні. Вісник Харків. нац. ун-ту ім. В. Н. Каразіна. Серія : Право. Харків. 2013. Вип. № 16 (1082). С. 198.

2 Навчально-методичний посібник для самостійної роботи та практичних занять і словник термінів з навчальної дисципліни «Криміналістика». С. 148.

3 Эксархопуло A. A. Специальные познания в уголовном процессе и их нетрадиционные формы. Вестник криминалистики. Москва : Спарк, 2001. Вып. 2. С. 2627. Россинская E. Р. Специальные юридические знания и судебно-нормативные экспертизы. Труды ВЮЗИ-МЮИ-МГЮА. Москва : МГЮА, 2006. Т. 2. С. 70. Лазарева Л. В. Специальные знания и их применение в доказывании по уголовному делу. Москва : Юрлитинформ, 2009. С. 22.

4 Кримінальний процесуальний кодекс України: наук.-практ. коментар / за заг. ред. В. Г. Гончаренко, В. Т. Нора, М. Є. Шумила. Київ : Юстініан. 2012. С. 539.

5 Про внесення змін до Господарського процесуального кодексу України, Цивільного процесуального кодексу України, Кодексу адміністративного судочинства України та інших законодавчих актів : Закон України від 03.10.2017 № 2147-VIII. Відом. Верхов. Ради. 2017. № 48. Ст. 436.

6 Щербаковский М. Г. Судебная экспертология и специальные знания эксперта. Теорія і практика судової експертизи і криміналістики : матеріали Всеукр. наук.практ. конф. $з$ нагоди 85-річчя д-ра юрид. наук, проф. Н. І. Клименко, Київ, 27 лютого 2018 р. Київ-Маріуполь. 2018. С. 402-403. 
При визначенні спеціальних знань традиційно в їх структуру включають уміння та навички ${ }^{1}$. Це положення викликає зауваження. У психології під навиком розуміють спосіб виконання дії, що в результаті тривалих вправ автоматизується ${ }^{2}$. Навик характеризується зменшенням або відсутністю свідомого контролю й регуляції. Уміння - це можливість здійснити будь-яку дію, операцію, розв'язати проблему. Умінням називають і реалізовану спробу діяльності, і високу професійну майстерність. Уміння, на відміну від навичок, утворюються в результаті координації навичок, їх об'єднання в системи за допомогою дій, які знаходяться під свідомим контролем. Уміння й навички взаємопов'язані та взаємозумовлені. Уміння, на відміну від навичок, завжди спираються на активну інтелектуальну діяльність і обов'язково включають процеси мислення ${ }^{3} .3$ іншого боку, уміння завжди $є$ застосуванням знань, тобто недостатньо просто знати щось про предмет, необхідно опанувати цілу низку дій і операцій для того, щоб застосувати ці знання. Отже, уміння - це цілеспрямоване оперування об'єктом на основі знання про нього. У цьому сенсі виконання дії на основі навичок стає автоматичним. Знання, уміння й навички - невіддільні та функціонально зв'язані, але різні частини будь-якої цілеспрямованої діяльності. Навички та вміння характеризують здатність обізнаної особи застосовувати знання, котрими вона володіє. На підставі викладеного вважаємо, що включення в поняття «спеціальних знань» умінь і навичок $є$ зайвим і не відповідає прийнятим у педагогіці та психології положенням. Крім того, зазначимо: щодо спеціаліста законом чітко розмежовуються наявність в обізнаної особи спеціальних знань і навичок (ст. 71 КПК України, ст. 74 ЦПК України, ст. 71 ГПК України, ст. 70 КАС України).

Певною рисою спеціальних знань $є$ спосіб їх опанування обізнаною особою. Усі дослідники сходяться на думці, що спеціальні знання отримуються в результаті навчання або тривалої практичної діяльності в якій-небудь галузі. Теоретичне навчання та практична діяльність - це процеси відображення й відтворення в людському мисленні об'єктивної дійсності, накопичення досвіду, засвоєння навичок, придбання вміння та знань як продуктів суспільно-трудової й розумової діяльності. Спеціальні знання набуваються шляхом формальної, неформальної та інформальної (самостійної) освіти. Формальна освіта реалізується засвоєнням освітніх програм навчання в закладах професійної (професійно-технічної), фахової передвищої та вищої освіти ${ }^{4}$. Отримання формальної освіти підтверджується відповідним документом.

1 Мельникова Э. Б. Участие специалистов в следственных действиях. Москва : Юрид. лит. 1964. С. 54. Кузьмічов В. С., Пиріг I. В. Використання спеціальних знань при розслідуванні розкрадань вантажів на залізничному транспорті : монографія. Дніпропетровськ : Ліра. 2008. С. 14. Бідняк Г. С. Використання спеціальних знань при розслідуванні шахрайств : дис. ... канд. юрид. наук : 12.00.09. Дніпро, 2018. С. 79.

2 Рубинштейн С. Л. Основы общей психологии. СПб. : Питер, 2000. С. 82.

3 Варій М. Й. Загальна психологія : підручник. Київ : Центр учб. літ., 2007. С. 689.

4 Про освіту : Закон України від 5.09.2017 № 2145-VIII. Відом. Верхов. Ради. 2017. № 38-39. Ст. 380. 
Дискусійним залишається питання щодо форм використання спеціальних знань. В. К. Лисиченко та В. В. Циркаль виступають категорично проти непроцесуальної форми використання спеціальних знань у кримінальному провадженні ${ }^{1}$. Більшість учених і практиків уважають можливим і необхідним використання спеціальних знань як у процесуальній, так і непроцесуальній формах ${ }^{2}$. У судочинстві широко застосовуються непроцесуальні форми використання спеціальних знань із метою отримання різного роду інформації: перевірки за криміналістичними обліками, попередні дослідження об'єктів за місцем їх виявлення, консультації фізичних або юридичних осіб тощо. Регулювання процесуальним законом використання спеціальних знань залежить від залученого учасниками процесу суб'єкта (обізнаної особи). Зазначимо, що в процесуальних законах можна виділити обізнаних осіб, правосуб'єктність та участь яких чітко регламентовано, і таких фахівців, результати роботи яких використовуються, але права, обов'язки, відповідальність, процедура діяльності чітко не визначені. Наприклад, у цивільному судочинстві продовження примусової амбулаторної психіатричної допомоги, примусової госпіталізації та ії̈ продовження (ст. 340 ЦПК України), а у кримінальному судочинстві продовження, зміна або припинення застосування примусових заходів медичного характеру (ст. 514 КПК України) здійснюються на підставі висновку комісії лікарів-психіатрів. Висновок обгрунтовує процесуальне рішення суду, однак, на відміну від судових експертів-психіатрів, правосуб'єктність зазначених фахівців законом не визначена.

Цілі використання спеціальних знань у судочинстві визначаються правниками по-різному, але близькі за змістом: усебічне, повне та об'єктивне з'ясування обставин, які входять у предмет доказування, або збирання та дослідження доказів ${ }^{3}$. Із цими твердженнями можна погодитися тільки частково. Дійсно доказова інформація включає відомості про обставини, що підлягають доказуванню та входять до предмета доказування. Проте трактування призначення спеціальних знань виключно отриманням доказів істотно звужує сферу їх використання. Крім доказової, за допомогою спеціальних знань отримується орієнтуюча інформація ${ }^{4}$. Так, спеціаліст надає

1 Лисиченко В. К. Циркаль В. В. Использование специальных знаний в следственной и судебной практике : учеб. пособие. Киев : Киев. гос. ун-т. 1987. С. 48.

2 Гончаренко В. И. Использование данных естественных и технических наук в уголовном судопроизводстве. Киев : Вища шк., 1980. С. 109; Ревака В. М. Зазнач. твір. С. 49; Криміналістика / за заг. ред. А. Ф. Волобуєва, Р. Л. Степанюка, В. О. Малярової : підручник: у 2 т. Харків : Харків. нац. ун-т внутр. справ. 2017. Т. 1. C. $48-49$.

3 Коваленко В. В. Застосування науково-технічних засобів спеціалістами при проведенні слідчих дій : монографія. Луганськ: РВВ ЛДУВС. 2007. С. 60. Кримінальний процесуальний кодекс України : наук.-практ. коментар / за заг. ред. В. Г. Гончаренко, В. Т. Нора, М. С. Шумила. Київ : Юстініан. 2012. С. 202; Кримінальний процес : підручник / за ред. В. Я. Тація, Ю. М. Грошевого, О. В. Капліної, О. Г. Шило. Харків : Право. 2013. С. 155.

4 Щербаковский М. Г., Кравченко А. А. Применение специальных знаний при раскрытии и расследовании преступлений : учеб. пособие. Харьков : Ун-т внутр. дел, 
рекомендації сторонам і суду щодо виду слідів, напряму їх пошуку або встановлення суб'єкта злочину; психолог може створити психологічний портрет злочинця тощо. Отримана за допомогою спеціальних знань орієнтуюча інформація використовується в організаційно-тактичних цілях в судочинстві для: висування версій, визначення напрямів розслідування, планування процесуальних дій, прогнозування можливої лінії поведінки учасників процесу тощо. Отже, цілями використання спеціальних знань $€$ отримання даних, що слугують підставами для прийняття обгрунтованих процесуальних або організаційних (тактичних) рішень. Крім того, спеціальні знання, зокрема висновок експерта в кримінальному судочинстві, використовуються в кримінально-правовому; кримінально-процесуальному; криміналістичному та кримінологічному напрямах ${ }^{1}$.

Підсумовуючи викладене, можна надати таке визначення: спецііальні знання - це систематизована інформація з різних галузей теоретичної та практичної діяльності, крім права, котру набувають в результаті професійного або самостійного навчання й досвіду з певної спеціальності, застосовують на основі умінь і навичок у процесуальній або непроцесуальній формах із метою збирання (формування), дослідження, перевірки доказів, установлення підстав для прийняття уповноваженими особами процесуальних, організаційних і тактичних рішень у судочинстві. Точний зміст, форма та ціль реалізації спеціальних знань залежать від функцій конкретного учасника судочинства, який їх використовує.

\section{СУЩНОСТЬ, СТРУКТУРА И ЦЕЛИ ИСПОЛЬЗОВАНИЯ СПЕЦИАЛЬНЫХ ЗНАНИЙ В СУДОПРОИЗВОДСТВЕ}

\section{Щербаковский М. Г.}

Раскрыты содержание и свойства процессуального понятия «специальные знания». Показано, что специальные знания включают совокупность систематизированных сведений или информации из различных сфер человеческой деятельности. Предложено отказаться от перечисления конкретных видов знаний (наука, техника, искусство, ремесло), которые в Криминальном процессуальном кодексе включены в понятие «специальные знания». Отмечены проблемные аспекты практической деятельности, которые возникают в связи с постановкой и решением экспертом вопросов правового характера. Автор, как и другие правоведы, считает, что только профессиональные участники судопроизводства (судья, следователь, прокурор, адвокат) решают правовые вопросы на основе своих юридчческих знаний. Поэтому в судопроизводстве знания из области права не могут относиться к спечиальным знаниям. На основе анализа литературных данных автор приходит к мнению, что наука о судебной экспертизе состоит из двух частей: общей

1999. С. 9; Садчикова К. А. Використання спеціальних знань на стадії досудового розслідування (процесуальний аспект) : дис. ... канд. юрид. наук : 12.00.09. Одеса, 2017. C. 37.

1 Щербаковський М. Г. Проведення та використання судових експертиз у кримінальному проваджені : монографія. Харків : В деле, 2015. С. 422-448. 
теории судебных экспертиз и методологических основ различных видов экспертиз. Методы и методики, используюшиеся в прочессе экспертных исследований и решении поставленных задач, относятся к специальным знаниям судебного эксперта. Исходя из принятых в педагогике и психологии положений, доказано, что умения и навыки сведущуего лииа не входят в состав специальных знаний. Специальные знания используются в судопроизводстве на основе умений и навыков участников процесса. Специильные знания приобретаются путем формального или неформального (самостоятельного) образования сведущего лица. В судопроизводстве иироко используются проиессуальные, которые регламентированы в кодексах, и непроиессуальные формы специильных знаний. Целью применения специиальных знаний является получение доказательственной или ориентирующей информации о правонарушении. Доказательственная информация является содержанием доказательств, а ориентирующая информация необходима для принятия прочессуальных, организационных или тактических решений следователем, прокурором, защитником и судьей.

Ключевые слова: специальные знания, судопроизводство, правовые знания, формы и цели использования специальных знаний.

\section{ESSENCE, STRUCTURE AND OBJECTIVES OF SPECIAL KNOWLEDGE USE FOR LEGAL PROCEEDINGS}

\section{Scherbakovskyi M. G.}

The article reveals the content and properties of procedural Special Knowledge concept. It is demonstrated that special knowledge includes a set of systematized data or information from various fields of human activity. It is proposed to refuse the listing of concrete types of knowledge (science, technology, art, craft), included in the concept of Special Knowledge for the Criminal procedure code. The problematic aspects of practical activities that arise in connection with the formulation and decision of legal issues by expert are highlighted. Author, like other lawyers, considers that only professional participants in legal proceedings (judge, investigator, prosecutor and lawyer) solve legal issues based on their legal knowledge. Therefore, in legal proceedings, knowledge from the field of law cannot relate to the special knowledge. Based on literature data analysis, the author comes to the conclusion that forensic science consists of two parts: forensic science general theory and the methodological grounds of various types of examinations. Methods and techniques used while expert research and solving assigned tasks are related to forensic expert Special Knowledge. Based on the provisions adopted by pedagogy and psychology, it is proved that the skills and abilities of competent person are not part of special knowledge. Special knowledge is used while legal proceedings based on the skills and abilities of trial participants. Special knowledge is acquired through formal or informal (independent) competent person education. Procedural knowledge regulated by codes and non-procedural forms of special knowledge are widely used while legal proceedings. The purpose of special knowledge applying is to obtain evidentiary or orientation information about the offense. Evidentiary information is the content of evidence and orienting information is necessary for procedural, organizational or tactical decisions to be done by the investigator, prosecutor, defense counsel and judge.

Keywords: special knowledge, legal proceedings, legal knowledge, forms and purposes of special knowledge use. 